\title{
The Impact of Microfinance on Poverty Reduction in Egypt: An Empirical Study
}

\author{
Dr. Hala H. El Hadidi \\ Associate Professor of Economics \\ Department of Business Administration \\ The British University in Egypt
}

\begin{abstract}
Microfinance became a critical aspect in the credit markets as an effective tool for poverty reduction and socioeconomic-development. Yet, the impact still questioned and varies from one country to another and from urban to rural areas. The aim of this paper is to examine the role of Egyptian microfinance on household income. A cross-sectional survey interviewed 780 from old and new clients in Greater Cairo and rural areas in Egypt. The stratified random method was used to collect the data from urban and rural districts. The finding of multinomial logistic reveals that Microfinance has positive impact on household income of women borrowers who spent three years in the scheme as compared to new borrowers who have not received treatment.
\end{abstract}

Keywords: Egyptian, Microfinance, Poverty Reduction, income.

\section{Introduction}

Microfinance is widely known as a provision of financial services such as credit, saving, deposit, insurance and repayment services to those who are deprived of accessing into conventional financial services because they are poor and they cannot offer collateral (Razavi, 2014; Littlefield, Murduch and Hashemi, 2015; Robinson, 2013). The underlying logic is that through extending financial services, low income people will have the ability to participate in the economic market and exploit entrepreneurial opportunities through start-up new businesses extending current business or introducing new activities.

Subsequently, they will be able to combat the poverty and satisfy their households' needs independently and consistently. In contrast, microfinance institutions will have the ability to develop their capacity through imposing a small ratio of interest on the given loans. A large size of microfinance studies from various disciplines suggest that microfinance has significant impact on poverty reduction as well as household wellbeing such as asset acquisition, household nutrition, health, food security, children education, women's empowerment, and social cohesion (Armendáriz de Aghion and Morduch, 2013; Amolat, 2016; Hashemi, Schuler, and Riley, 2016; Littlefield et al., 2015; Roodman and Morduch, 2015). However, recently the impact of microfinance has been questioned and many studies argue that the impact of microfinance is divergent between positive, no impact and even negative impact (Angelucci, Karlan and Zinman, 2013; Ghaliba et al., 2015 and Swain et al., 2015; Rooyen, Stewart, and de Wet, 2015). The literature claims that the impact of microfinance works differently from one context to another and the impact is dependent on the population density, at-

* This article was submitted in November 2018, and accepted for publishing in March 2019, Published: June 2020.

(c) Arab Administrative Development Organization- League of Arab States, 2020, pp 289-296، D DOI: 10.21608/aja.2020.88344 
titudes to debt, group-cohesion, enterprise development, financial literacy, financial service providers and other (Armendáriz, Aghion and Morduch, 2013).

The Egyptian microfinance plays an important role in socioeconomic development of poor and low income people especially women (Agnes, 2016; Al-Shami et al., 2016). Despite, the significant impact of Egyptian microfinance which was highlighted by several studies, the majority of these studies were conducted in rural areas and used simple statistic tools such as T test, Mann-Whitney which is exposure to several weaknesses such as bias selection and the lack of controlling the effect of demographic characteristics (Hashemi et al. 2016). The aim of this paper is to evaluate the impact of Egyptian microfinance on women livelihood in Greater Cairo and selected Rural districts. The main reasons of selecting these two districts is due to the fact that they have the fastest growth urbanization ratio and over than $75 \%$ of population are living in urban. Second, over than $70 \%$ of Microfinance clients in Egypt are living in urban areas.

The aim of the Microfinance institution is to extend loans and other financial services to women who are deprived of formal financial services because of the lack of collateral. The reason of targeting women is owed to the significant role that women play in their household enhancement. The Microfinance institution covers approximately 82\% of Egyptian poor and low income households (Al-Shami et al., 2016). According to the Microfinance institution annual report 2013, about 346,245 women clients throughout the country benefited from Microfinance (Druschel, 2016).

\section{Literature Review and Hypotheses}

Microfinance has been widely recognized as a crucial tool for poverty alleviation and socioeconomic wellbeing. It helps the poor to diversify the household income, smoothen the household expenditure and enable them to cope with economic shocks and fluctuations (Amolat, 2016; Littlefield, Murduch \& Hashemi, 2015; Robinson, 2013).

Microfinance is shown to have a positive effect on poverty reduction at macro level (Imai et al. 2016), Microfinance plays an important role on poverty reduction and socioeconomic development in Sub-Sahara Africa countries (Rooyen et al,. 2015). The Egyptian microfinance has positive effect on economic vulnerability among hard-core poor households (Al-mamun et al., 2014). Study by (Ghaliba et al., 2015), emphasizes that Pakistani microfinance has positive impact on poverty alleviation which was manifested in household income and expenditure especially in clothing and health.

According to the finding of panel data, Bangladeshi microfinance was found to have positive effect on poverty reduction and household expenditure especially food and non-food (Salib, 2014). The Uganda microfinance has a positive impact on the rural clients «households» income diversification and assets accumulation (Morris and Barnes, 2013). Based on retrospective data gathered from Guatemala, India, and Ghana microfinance instructions, the impact of microfinance was shown to be positive on borrowers' households as well as businesses (Nader, 2016; Oxaal et al., 2013).

Microfinance has positive impact on the borrowers' income especially in urban areas in India (Imai et al., 2016). The Zimbabwe microfinance has positive impact on poverty reduction and the average income of microfinance clients was more than the average income of new clients or non-clients (Morduch and Graduate, 2015).

Therefore, the hypothesis of this study is that: Microfinance loan has positive effect of household income of women borrowers. 


\section{Microfinance Methodology}

Basically, the scientific approach of impact assessment methodologies such as randomized control trait and quasi-experimental are important to assess the impact of microfinance intervention. Yet, it is very difficult to employ these type of methods and also costly (Karlan, 2012; Swain and Varghese, 2015). To find a middle method between rigor, expensive methods and reliable method, the Microfinance project suggests a middle method where new clients can be used as a control group. The use of new clients as control group is more efficient for saving time and cost and researcher does not need to go over longitudinal survey (Karlan, 2012). The new clients were used as control group in many microfinance studies to name (Salib, 2014; Hiatt and Woodworth, 2013; Karlan, 2012; Kondo et al., 2014; Swain and Varghese, 2015; Ledgerwood, 2014).

This study used new clients as a control group.

\section{Sample Selection}

A survey of 780 women conducted as shown in Table 1, four separate samples were drawn, using a random multistage cluster design to include fourteen districts from Greater Cairo and selected rural areas in Egypt. The four groups consisted of old members from Greater Cairo and (those who joined Microfinance scheme in 2010 and continued until $2014=360$ ), new clients from Greater Cairo (those who joined the Microfinance scheme in 2014 and have not yet used their loans = 140), old members from rural Egyptian areas (those who joined the Microfinance scheme in 2010 and continued until $2014=180$ ), and new clients from rural Egyptian areas (those who joined the Microfinance scheme in 2014 and have not yet used their loans =100). The conducted survey includes questions related to women household expenditure.

\section{Operational Definitions of Survey Variables}

The poverty line income was widely recommended to be used in measuring the impact of microfinance Table 1. The distribution of collected data

\begin{tabular}{cccccc}
\hline \multicolumn{2}{c}{ Greater Cairo } & & \multicolumn{2}{c}{ Rural areas } & \multirow{2}{*}{ Total } \\
\cline { 1 - 5 } \cline { 4 - 6 } Old Clients & New Clients & Old Clients & New Clients & \\
\hline 80 & 40 & 100 & 60 & 280 \\
\hline 320 & 140 & 220 & 100 & 780 \\
\hline
\end{tabular}
on household level to name (Johnson and Rogaly, 2012; Navajas et al., 2012; Kabeer, 2015). In this research, dependent variable is household income which was adopted from Egyptian poverty line (Barsoum, 2015; Nader, 2016, Rahman; 2015) in three categories namely extreme poverty (households with monthly income equals or below EGP 440, poor (households with monthly income equals or below EGP 750 and finally low income (household with monthly income equals or below than EGP 2000. The extreme poverty group was selected as reference category.

\section{Research Analysis}

\section{Descriptive Analysis and Problem of Bias Selection}

Table 2, illustrates simple comparison in the demographic characteristics between urban and rural areas. First, the urban clients were divided into two groups' namely 360 of old clients who joined Microfinance scheme in 2010 and still active and 180 of new clients who joined Microfinance in the early of 2014 and have not used their loans yet. Second, rural clients were divided into two groups namely 180 of old rural clients who joined Microfinance scheme in 2010 and still active and 100 of new rural clients who joined Microfinance scheme in 2014 and have not used their loans. The analysis process contains four control variables related to women demographic and socioeconomic characteristics. These are respondents' age (coded in single year), number of chil- 
dren (coded number), number of dependents in household (coded in numbers), have saving account (coded dummy in which those who have saving account 1 , and these who don't have 0), and marital status (coded binary in which married women coded 1 and others 0 ), the level of education coded ordinal in which (1 refers to secondary and above, 2 middle school, and 3 primary school). This comparison allows for initial estimations of program impact.

Table (2) demonstrates some selection bias, the differences between the four groups is not large. Members in
Table 2. Descriptive Analysis

\begin{tabular}{ccccc}
\hline Variables & $\begin{array}{c}\text { Old clients } \\
\text { Urban }\end{array}$ & $\begin{array}{c}\text { New clients } \\
\text { Urban }\end{array}$ & $\begin{array}{c}\text { Old clients } \\
\text { Rural }\end{array}$ & $\begin{array}{c}\text { New cli- } \\
\text { ents Rural }\end{array}$ \\
\hline $\mathrm{N}$ & 360 & 140 & 180 & 100 \\
\hline Mean of Age & 38.55 & 37.29 & 38.6 & 36.9 \\
\hline Household size & 5.05 & 4.86 & 1.91 & 1.96 \\
\hline Saving account & $243(67.5 \%)$ & $74(52.9 \%)$ & $73(40.6 \%)$ & $23(23 \%)$ \\
\hline $\begin{array}{c}\text { Access to loan before joining } \\
\text { the Microfinance scheme }\end{array}$ & $156(43.3 \%)$ & $74(52.9 \%)$ & $75(41.7 \%)$ & $52(52 \%)$ \\
\hline Access to Business training $226(62.8 \%)$ & $73(52.1 \%)$ & $96(53.3 \%)$ & $44(44 \%)$ \\
\hline Secondary school and above & $141(39.2 \%)$ & $65(46.4 \%)$ & $68(37.8 \%)$ & $41(41 \%)$ \\
\hline Middle school & $184(51.1 \%)$ & $65(46.4 \%)$ & $88(48.9 \%)$ & $51(51 \%)$ \\
\hline Primary school & $35(9.7 \%)$ & $10(7.1 \%)$ & $24(13.3 \%)$ & $8(8 \%)$ \\
\hline <EGP 440 & $41(11.4 \%)$ & $40(28.6 \%)$ & $39(21.7 \%)$ & $54(54 \%)$ \\
\hline >EGP 750 & $267(74.2 \%)$ & $95(67.9 \%)$ & $120(66.7 \%)$ & $40(40 \%)$ \\
\hline >EGP 2000 & $52(14.4 \%)$ & $5(3.6 \%)$ & $21(11.7 \%)$ & $6(6 \%)$ \\
\hline
\end{tabular}
urban and rural areas are one to two years older in average than new clients and there are no significant differences in the number of children and household dependents. The percentage of those who have secondary school and above is slightly higher among new clients as compared to old clients. The percentage of those who accessed to loan services before joining the Microfinance scheme is slightly higher among new borrowers in both urban and rural by approximately $9 \%$ and $10 \%$ respectively. The percentage of those who accessed to business training is higher in old clients either in urban or rural by approximately $10 \%$. Finally, the percentage of those who have saving account is higher in the old clients either in urban or rural by $14 \%$ and $18 \%$ respectively.

\section{Household Income in Urban}

The distribution reveals that the probability of the model chi-square 60.17 is $0.000<0.05$. The null hypothesis that states there is no difference between the model without independent variables and the model with independent variables was rejected. The Deviance statistic here demonstrates that the model is a good fit of the data ( $p=.524$, which is significantly higher than .05). The Nagelkerke $R^{2}$ value of .145 indicates the model is useful in predicting household income. Finally, the classification table for analysis of the effect of microfinance on household income as shown in Table 3 suggests a 73\% correct prediction, which is well above the criteria for chance accuracy of $57.4 \%$.

This indicates that the criteria for classification accuracy are satisfied for the analysis. As shown in Table3, model one show the relationship between access to Microfiance loan and the household income of low income women (those whose household income equals or less than EGP 750) at urban areas. The odd ratio (Exp (B) indicates that likelihood of the household income of treatment group (old clients) increase by 1.5 as compared to new clients. Model one also shows other control variables that have positive significant effects on household income. For example, the odd ratio of 1.3 indicates that increase the size of household by one unit leads to increase household income by 0.3 . The odd ratio of 2.1 indicates that access to business training leads to increase household income by 1.1. However, the odd ratio of 0.489 , indicates that access to saving account leads to decrease household income by 0.51.This indicates that women who have saving account used their surplus in saving account rather than contributing to household income. In addition, model two shows the relationship between access to Microfinance loan and the household in- 
come of women borrowers whose household income equals or less than EGP 2,000. The odd ratio (Exp (B) of 2.3 indicates that likelihood of the household income of treatment group (old clients) increase by 2.5 as compared to new clients. Model one also shows other control variables that have positive significant effects on household income. For example, the odd ratio of 1.1 indicates that increase the age leads to increase household income by 0.1 . The odd ratio of 1.85 indicates that increase the size of household by one unit leads to increase household income by 0.85 . The odd ratio of 2.7 indicates that access to business training leads to increase household income by $1.7 \%$.

\section{Household Income in Rural}

The distribution reveals that the probability of the model chi-square 34.61 is $0.000<0.05$. The null hypothesis that states there is no difference between the model without independent variables and the model with independent variables was rejected. The Deviance statistic here demonstrates that the model is a good fit of the data ( $p=.945$, which is significantly higher than .05). The Nagelkerke $\mathrm{R}^{2}$ value of .138 indicates the model is useful in predicting household income. Finally, the classification table for analysis of the effect of microfinance on household income as shown in Table 3 suggests a 61\% correct prediction, which is well above the criteria for chance accuracy of $43.47 \%$.

This indicates that the criteria for classification accuracy are satisfied for the analysis. Table 3 shows model one which illustrates the relationship between access to Microfinance loan and the household income of low income women (those whose household income equals or less than EGP 750) at rural areas. The odd ratio (Exp (B) of 3.3 indicates that likelihood of the household income of treatment group (old clients) increase by 2.3 as compared to new clients. Model one also shows other control variables that have positive significant effects on household income. For example, the odd ratio of 1.38 indicates that increase the size of household by one unit leads to increase household income by 0.38 . Table 3 shows model two which illustrates the relationship between access to Microfinance loan and the household income of women borrowers whose household income equals or below EGP 2,000 at rural areas. The odd ratio (Exp (B) of 4.27 indicates that likelihood of the household income of treatment group (old clients) increase by 3.27 as compared to new clients.

\section{Discussion}

Table 3, demonstrates the result of multinomial logistic regression on the effect of access to microcredit on women household income in urban and rural provinces in Egypt. The finding of Table 3, indicates that access to microcredit has positive impact on old clients' household income as compared to new clients. The literature suggests that microfinance enables women to participate in economic market through forming and extending their micro and small businesses and generate independent income that allows them to contribute to their household income. The literature also points that access to microfinance enables poor and low income borrowers especially women to diversify their livelihood and alleviate their venerability. For example, microfinance has positive effect on poverty reduction and household income (Al-mamun et al., 2014), household expenditure (Ghaliba et al., 2015), food and non-food expenditure (Nader, 2016) or income diversification and assets accumulation (Morris and Barnes,2013). However, recent studies such as (Sen, 2015; Razavi, 2014; Nader, 2016) found that microfinance is not a bullet magic in poverty reduction and it may has negative impact. While (Nader, 2016; Oxaal, 2013; Salib, 2014), argues that microfinance works differently from one context to others and from rural to urban the population density, attitudes to debt, group-cohesion, enterprise development, financial literacy, financial service providers and other. In line with this study, the Egyptian microf- 
inance has positive impact on poverty reduction and women household income especially in rural areas.

The result of this study highlighted the importance of control variables that have positive impact on women household income. For instance, access to business training has positive impact on women household income. This indicates that women with knowledge about business are more able to make profit and enhance their business revenue. The finding of this study is in consensus with study by (Engle, 2015; Nader, 2016) in the importance of extending nonfinancial services such as business development and entrepreneurship training to women clients before providing them loans (Anderson et al, 2016; Drolet, 2015).

\section{Implication of the Research and Conclusion}

The findings of this study have several main implications for the academic, microfinance institutions and the policymakers. For the academic, this study added new evidence on the impact of microfinance on socioeconomic development of low income household especially women who cannot access to financial services due to their poverty. It helps them to diversify their household income and alleviate their poverty. This study provides an insight about the role of microfinance on women empowerment in the urban and rural developing country from the perspective of Egyptian context. In a similar vein, this study suggests that microfinance has the ability to contribute significantly to the achievement of new economic policy and new economic model through enhancing the socioeconomic wellbeing of poor and low income people especially women. It also plays a central role in creating jobs for women especially those with low education. Therefore microfinance opens an opportunity for women borrowers to play significant role in economic development. Despite of the significant impact of Microfinance on household income, a large number of old clients have not graduated from the scheme and become financially self-sufficient. This issue should be addressed by the policy-makers of Egyptian government in how to transform the strategy of socioeconomic wellbeing from relying on credit as a source of income to build their capacity. Therefore, future research should pay attention on how to improve the sustainability and growth of micro and small businesses that are financed by microfinance. 


\section{References}

Agnes, Y. (2016). «Engendering Microfinance Services: Beyond Access», Paper Presented at the Women's Empowerment or Feminisation of Debt Workshop, London, March.

- $\quad$ Al-mamun, Abdullah; Mohammad, Nurul; Huda, Mazumder \& Malarvizhi, C. A. (2014). Measuring the Effect of Amanah Ikhtiar Malaysia's Microcredit Programme on Economic Vulnerability among Hardcore Poor Households. Progress in Development Studies, 1, 49-59.

- $\quad$ Al-Shami, Sayed; Samer, Ali; Izaidin Bin Adbul Majid; Nurulizwa Abdul Rashid \& Mohd Syaiful Rizal Bin Abdul Hamid. (2016). «Conceptual Framework: The Role of Microfinance on the Wellbeing of Poor People Cases Studies from Malaysia and Yemen», Asian Social Science, 10 (1), 230-42.

- $\quad$ Amolat, F. R. (2016). Client Impact Assessment: KMBI Program Impact Assessment for Microfinance Implementation for Region 1.

- $\quad$ Anderson, L.; Locker, L.; Nugent, R. (2016). «Microcredit, Social Capital, and Common Pool Resources», World Development, Vol. 30, No.1, 95-105.

- $\quad$ Angelucci, Manuela; Dean S., Karlan \& Jonathan, Zinman. (2013). Win Some Lose Some? Evidence from a Randomized Microcredit Program Placement Experiment by Compartamos Banco. Institute for the Study of Labor (IZA), 7439,71.

- Armendáriz; Beatriz; Aghion \& Jonathan Morduch. (2013). «The Economics of Microfinance», Economic Record, 82, 491-92.

- $\quad$ Armendáriz de Aghion \& Morduch, J. (2013). «Microfinance beyond Group Lending», Economics of Transition, 8, (2), 401-20.

- Barsoum, Ghada. (2015). «Who Gets Credit? The Gendered Division of Microfinance Programs in Egypt», Canadian Journal of Development Studies, 27, (1), 51-64.

- $\quad$ Drolet, J. (2015). Women, Microcredit and Empowerment in Cairo, Egypt, International Social Work. Vol. 5, pp. 23-35.

- $\quad$ Druschel, K. (2016). State of the Microcredit Summit Campaign Report. Washington, D.C.: Microcredit Summit Campaign Secretariat.

- Engle, P. (2015). «Father's Money, Mother's Money, and Parental Commitment: Guatemala and Nicaragua.» In: RaeLesser Blumberg et al. Boulder, Colo (eds.) Engendering Wealth and Well-Being: Empowerment for Global Change. Westview Press. 20

- $\quad$ Ghaliba, Asad K.; Issam, Malki \& Katsushi, S. Imai. (2015). Microfinance and Household Poverty Reduction: Empirical Evidence from Rural Pakistan. Oxford Development Studies, 84-104.

- Hashemi, S. M.; S. R. Schuler \& A. Riley. (2016). «Rural Credit Programs and Women's Empowerment in Bangladesh», World Development, 24 (4), 635-53.

- Hiatt, Shon R. \& Warner P. Woodworth. (2013). «Alleviating Poverty Through Microfinance: Village Banking Outcomes in Central America|, The Social Science Journal, 43 (3), 471-77.

- Imai, Katsushi S., Raghav, Gaiha, Ganesh, Thapa, \& Samuel, Kobina Annim. (2016). «Microfinance and Poverty: A Macro Perspective|, World Development, 40 (8), 1675-89.

- Johnson \& Rogaly. (2012). Microfinance and Poverty Reduction. UK and Ireland: UK: Oxfam.

- Kabeer, Naila. (2015). Resources, Agency, Achievements: Measurement of Women'Empowerment. Blackwell Publishing Limited, 30(May), 435-64.

- Karlan, Dean. (2012). «Cross Sectional Impact Analysis: Bias from Dropouts», Microfinance Journal (December). Vol. 3; No. 2, pp. 343-366. 
Kondo, Toshio, Aniceto, Orbeta Jr., Clarence ,Dingcong, \& Christine, Infantado. (2014). «Impact of Microfinance on Rural Households in the Philippines», IDS Bulletin, 39 (1), 51-70.

- Ledgerwood, Joanna. (2014). Microfinance handbook: An Institutional and Financial Perspective. Washing. World Bank.

- $\quad$ Littlefield, Elizabeth, Jonathan Murduch, \& Syed Hashemi. (2003). Is Microfinance an Effective Strategy to Reach the Millennium Development Goals?, https://www.mikrofinanzwiki.de/file/570/ is_mf_an_effective_strategy_to_reach_the_mdg_2003.pdf

- Morduch, Jonathan, \& Robert F. Wagner Graduate. (2002). Analysis of the Effects of Microfinance on Poverty Reduction. NYU Wagner Working Paper No. 1014, Issued June 28.

- Morris, Gayle \& Carolyn Barnes. (2013). «An Assessment of the Impact of Microfinance», Journal of Microfinance, 7 (1), 39-54.

- Nader, Y. (2016). «Microcredit and the Socio-economic Wellbeing of Women and their Families in Cairo», The Journal of Socio-economics, 37 (2008) 644-656. No. 1. pp: 45-63.

- Navajas, Sergio, Mark, Schreiner, Richard L., Meyer, Claudio, Gonzalez-vega \& Jorge, Rodriguez-meza. (2012). Microcredit and the Poorest of the Poor: Theory and Evidence from Olivia. World Development, 28 (2), 333-46.

- $\quad$ Oxaal, Z., Baden, S. (2013). Gender and Empowerment: Definitions, Approaches and Implications for Policy. Institute of Development Studies. University of Sussex, UK. Vol. 3, pp 532-556.

- Rahman, A. (2015). «Micro-credit Initiatives for Equitable and Sustainable Development: Who Pays?»World Development, 27, No. 1. pp: 67-82.

- Razavi, S. (2014). «From Rags to Riches: Looking at Poverty from a Gender Perspective», IDS Bulletin, 28, No. 3. pp: 49-62.

- $\quad$ Robinson., Marguerite. (2013). The Microfinance Revolution Sustainable Finance for the Poor. Washington, US: World Bank.

- $\quad$ Roodman, David \& Jonathan, Morduch. (2015). Impact of Microcredit on the Poor in Bangladesh: Revisiting the Evidence. Washington.

- $\quad$ Rooyen, C., R. Stewart \& T. De Wet. (2015). «The Impact of Microfinance in Sub-saharan Africa: A Systematic Review of the Evidence», World Development, 40, 2249-62.

- Salib, S. (2014). «FORA's Impact among Migrants: Primary Findings», Oak Brook, III.: Opportunity International Network. Vol. 3, pp. 56-82.

- Sen, G. (2015). «Engendering Poverty Alleviation: Challenges and Opportunities», Development and Change. Vo. 2. No. 30. pp: 685-92.

- Swain, Ranjula Bali \& Adel, Varghese. (2015). «Does Self help Group Participation Lead to Asset creation?», World Development, 37, 1674-82 